University of Wollongong

Research Online

Faculty of Social Sciences - Papers (Archive) Faculty of Arts, Social Sciences \& Humanities

2015

Knowledge of, beliefs about, and perceived barriers to organ and tissue donation in Serbian, Macedonian, and Greek Orthodox communities in Australia

Lyn Phillipson

University of Wollongong, Iphillip@uow.edu.au

Karen M. Larsen-Truong

University of Wollongong, karenlt@uow.edu.au

Leissa Pitts

leissa.pitts@sesiahs.health.nsw.gov.au

Miriam Nonu

Illawarra Shoalhaven Local Health District

Follow this and additional works at: https://ro.uow.edu.au/sspapers

Part of the Education Commons, and the Social and Behavioral Sciences Commons

Research Online is the open access institutional repository for the University of Wollongong. For further information contact the UOW Library: research-pubs@uow.edu.au 


\title{
Knowledge of, beliefs about, and perceived barriers to organ and tissue donation in Serbian, Macedonian, and Greek Orthodox communities in Australia
}

\begin{abstract}
Context-Despite the lifesaving benefits of organ and tissue donation, a worldwide shortage of suitable and registered donors exists. Although the reasons for this shortage are multifactorial, it has been recognized that distinct barriers to registration, family discussion, and consent that require targeted intervention and action are present among minority cultural, religious, and immigrant communities. Objective-To explore the knowledge, attitudes, and beliefs of 3 orthodox religious communities in Australia (Macedonian, Greek, and Serbian Orthodox) and determine the implications for engaging with these communities to improve knowledge, attitudes, family discussion, and the ability to make an informed decision about donation. Design-Qualitative approach using focus groups moderated by researchers and bicultural health workers with the assistance of accredited interpreters. Participants-98 adult members of the Greek, Macedonian, and Serbian Orthodox communities in the Illawarra region of New South Wales, Australia. Results-Clear barriers to discussing and making an informed decision about organ and tissue donation were identified. Knowledge of processes and procedures was low and discussion about death (and organ and tissue donation) with family members and loved ones was considered taboo. Despite these barriers, all 3 communities expressed a desire for more information and engagement. Of particular interest were the perspectives of 3 types of "experts": medical, religious, and other community members (who had experience with the organ and tissue donation system). Future programs designed for orthodox religious communities should consider the need for active strategies that facilitate information sharing and engagement between community members and these 3 types of experts.
\end{abstract}

\section{Keywords}

donation, serbian, macedonian, knowledge, greek, beliefs, orthodox, communities, australia, about, perceived, barriers, organ, tissue

\section{Disciplines}

Education | Social and Behavioral Sciences

\section{Publication Details}

Phillipson, L., Larsen-Truong, K., Pitts, L. \& Ms Miriam Nonu, M. (2015). Knowledge of, beliefs about, and perceived barriers to organ and tissue donation in Serbian, Macedonian, and Greek Orthodox communities in Australia. Progress in Transplantation: the journal for procurement and clinical transplant professionals, 25 (1), 91-99. 


\title{
Lyn Phillipson, Karen Larsen-Truong, Leissa Pitts, Miriam Nonu
}

\author{
Phillipson, L, Larsen-Truong, K, Pitts, L and Nonu, M. (2015). Knowledge of, beliefs \\ about, and perceived barriers to organ and tissue donation in Serbian, Macedonian, \\ and Greek Orthodox communities in Australia. Progress in Transplantation: March \\ 2015, Vol. 25, No. 1, pp. 91-99. DOI:10.7182/pit2015550
}

\section{BACKGROUND}

Organ transplantation is an accepted worldwide practice that has saved hundreds of thousands of lives and improved the quality of countless more $(1,2)$. In the United States (US) over 20,000 transplants were made in the past year, while over 75,000 candidates were on the active waiting list (3). While the rates of organ donation and transplants vary from country to country, there is a universal shortage of organ donors. In Australia there were 1,052 transplant recipients in 2012, however, at any time around 1600 people are registered on the transplant waiting list (4).

Similar to the US and the United Kingdom, Australia has an 'opt in' system where potential donors must voluntarily register (5). Research shows that the overwhelming majority of Australians are willing to become organ (78\%) and tissue (75\%) donors (6). However, despite these positive attitudes, only $11.7 \%$ of Australians aged over 16 years have legally valid consent registrations on the Australian Organ Donor Register (7). In Australia, the consent of the family of the deceased is always obtained (6). However, approximately $47 \%$ of Australians do not know or are unsure about the donation wishes of their loved ones. This is likely to be one of the key reasons why the family consent rate is low, with only $61 \%$ of families giving consent for organ and tissue donation to proceed (6).

In order to increase donor rates it is necessary to identify specific factors inhibiting and facilitating organ and tissue donation attitudes and behaviours including joining a register and discussing that decision with family. An international review found that factors facilitating positive attitudes and a willingness to donate include age, gender, education, socioeconomic status, knowledge, altruistic tendencies and having personal experience with organ donation, and perceived familial influence (5). However, the review also found that ethnicity, strong religious beliefs and concern about disfigurement of the body were negative predictors of willingness to donate (5). A study of Australian university students from a range of religious and ethnic backgrounds found that females, younger Australians and those with high knowledge levels were more willing to donate, as well as persons who described themselves as having stronger religious beliefs (8).

International research into minority ethnic communities includes; Hispanic Americans (9-12), African Americans (11-16); Asian Americans (11, 12, 17); Native Americans (10); Turkish communities (18); English of African descent (19); and Middle Eastern communities (20-22). Common barriers to organ donation in minority ethnic groups 
include; general lack of awareness about organ donation (21), religious myths and misperceptions (20), and low rates of family discussions (9).

Linked to ethnicity are cultural perceptions and religious influences. A study conducted in the US in 2003 (23) found that individuals who rated themselves as higher in religiousness were more likely to be less accepting of organ donation. They found that religious beliefs particularly influenced the individual's attitude in relation to opposition to organ donation. A study conducted in Pakistan (22) found that people who believed that their religion doesn't allow organ donation showed no motivation to donate in the future. Conversely they found the belief that organ donation was allowed by religion was a significant independent predictor of willingness to donate. A similar finding was made in a US study, that people were more likely to show a willingness to donate if they anticipated the support of a religious leader, and anticipated the support of the religious community (24).

An important barrier identified across a variety of cultural minority groups was a pervasive distrust in the medical system $(10,15-17,20)$. Medical distrust includes issues such as; perceptions of (or experiences of) discrimination in the health system, concern that medical staff may not perform all lifesaving procedures if a patient is a registered organ donor, belief in unfair allocation of resources (e.g. belief that wealthy people receive better medical care) and uncertainty in medical procedures used to determine organ donation eligibility.

Understanding such culturally specific barriers and using them to inform culturally appropriate interventions have proven to have positive effects on knowledge, attitudes, and behaviour $(9,25)$. However, the beliefs, attitudes and other barriers which may exist within many immigrant communities within Australia, remain a mystery, despite the established lower rates of registration and family consent (26).

\section{Current Study}

Most organ donors in Australia are Caucasian (322 of the 337 donors in 2011) with only small numbers of donors of Aboriginal, Torres Strait Islander or other nonCaucasian heritage (27). In the US, whilst donation representation in the population is proportional, the need for transplant in some minority ethnic groups is higher due to a higher incidence of conditions benefitting from transplant (28). In response, both the US and Australian governments have identified people of culturally and linguistically diverse backgrounds as priority groups for a range of initiatives to (28, 29). In Australia, research commissioned by the Organ and Tissue Authority shows that culturally and linguistically diverse audiences are less likely to have held memorable family discussion or made decisions about organ and tissue donation (26). The same research specifically identified Orthodox (particularly Greek Orthodox) as a priority group for engagement.

Only one research study was identified that specifically considered Greek Orthodox religion and this was conducted in Greece (30). They found that $63.7 \%$ of Greek Orthodox citizens would like to be registered as donors. However, to date, there has 
been no published research which explores the attitudes, beliefs and behaviours of Greek, or other Orthodox religious communities in Australia.

The purpose of this paper is to summarise the insights drawn from formative research conducted with Macedonian, Greek and Serbian Orthodox community members from the Illawarra in Australia to gain insight into their attitudes and beliefs relating to organ donation. According to the 2011 census there were 14, 470 people who identified as Eastern Orthodox resident in the Illawarra region of NSW, Australia. In the region, 18133 (17.8\%) of the population speak a language as well as English at home. Of these, 6918 (38\%) of the regional NESB population) spoke Macedonian language at home, whilst 2217 (12.2\%) Greek and 1825 (10\%) spoke Serbian when at home (31). Initial discussion with community leaders suggested that for these communities, organ and tissue donation had not been a topic of considerable thought, discussion or decision making. The study was conducted with the aim of understanding current perspectives on organ and tissue donation as well as identifying barriers within the communities to seeking information, registering as a potential donor and importantly, family discussion of organ and tissue donation wishes. The results of this research informed the development of a social marketing intervention which has been described elsewhere (32).

\section{METHOD}

\section{PARTICIPANTS}

A convenience sample of adult participants was recruited via local community and cultural groups and local Orthodox Church congregations with the assistance of bicultural workers employed by the Local Health District Multicultural Health Service.

\section{PROCEDURES}

Participants were recruited through the distribution of information sheets and flyers in English and community languages via local cultural groups and networks. Focus groups were conducted with volunteer participants who provided written consent for their participation. A health care interpreter and bicultural health worker were recruited to assist in overcoming language barriers and assisting with the process of cross-cultural enquiry within the focus groups $(33,34)$. Separate focus group discussions were held in community based or church facilities for each of the Greek, Macedonian and Serbian Orthodox communities in the lllawarra during November and December 2011. A semi-structured exploratory approach was taken utilising a discussion guide developed by the research team to provide insights into community knowledge, attitudes and beliefs regarding organ and tissue donation, and to inform messages and strategies for the social marketing campaign. The discussion guide included the following topics:

- knowledge and attitudes regarding organ and tissue donation

- personal experience regarding organ and tissue donation

- barriers (personal, cultural and religious) to discussing organ and tissue 
donation

- barriers (personal, cultural and religious) to consenting to organ and tissue donation

- future intentions regarding discussion, registration and donation.

The facilitator also discussed preferred strategies for the distribution of information and educational materials including where community members would be most likely to see or seek such materials, specifically:

- where they would go to seek information about health

- trusted sources of information about health (family, friends, doctor, religious leaders)

- media sources (print, digital, TV and radio).

A current television advertisement promoting family discussion and organ donation registration was also shown (in English and interpreted into the appropriate community language) as a stimulus to explore awareness, relevance and perceptions of the information campaign (35).

Prior consultation undertaken by the bicultural health workers highlighted the sensitive nature of the topic and the likelihood that focus group discussions would raise questions for participants. As such, the bicultural workers were available at each session to provide support and/or referral as necessary. A trained Organ and Tissue Donor Coordinator from the Local Health District Organ and Tissue Donor Service was also present at each focus group. At the conclusion of each group the Coordinator gave a short presentation on organ and tissue donation and addressed questions and concerns raised during the focus group.

Each focus group discussion was professionally transcribed for subsequent analysis by two trained qualitative researchers. The analysis followed a systematic and iterative process, including identification of major themes and classification of data from each focus group (36). Areas of interest including identifying knowledge and attitudes regarding organ and tissue donation; barriers to discussing organ and tissue donation; barriers (personal, cultural and religious) to consenting to organ and tissue donation. Community perceptions of culturally appropriate strategies to promote knowledge, discussion and decision making were also coded. Separate analyses from each researcher were compared and discrepancies discussed with a third researcher until consensus was reached. Quotes that represent the essence of each theme are presented in the results. Consultation with bicultural health workers was also undertaken to ensure consideration of the issues arising from interpreter assisted focus groups $(34,37)$ and the benefits of informed discussions to triangulate and explore the cultural richness within the data (33). Potential bias in analysing results were also minimised through a number of the strategies outlined including the use of two trained researchers to analyse the data and consultation with bicultural health workers who were also present at the focus groups and had access to the 
transcripts. The study protocol and materials were reviewed and approved by the University Human Research Ethics Committee.

\section{RESULTS}

In total, 11 focus groups were conducted with 98 members of the Macedonian (4 groups); Serbian (4 groups) and Greek (3 groups) Orthodox communities in November 2011 . The average age of community members participating in focus groups was 55, with an age range of 20 to 84 . The majority of participants were female $(62 / 98,63 \%)$. From the focus group discussions key knowledge gaps, attitudes, beliefs and behaviours were identified. There were no significant differences between the themes identified within the three cultural groups (Greek, Macedonian and Serbian). As such combined results are presented for the three communities.

\section{Sources of knowledge regarding organ and tissue donation}

Exposure to organ and tissue donation messages was generally via passive or indirect exposure, rather than as a result of active searching for information. Situations where community members were exposed to organ and tissue donation messages included: completing driving licence renewal forms visiting a Medicare office, seeing stories in the media (e.g. movies, reality television shows organ donation adverts), or experiencing (or knowing someone who had experienced) organ and tissue donation. Public awareness campaigns that included television advertisements were shown at the commencement of the focus groups. Community members consistently showed little or no recognition of these ads and promotions, suggesting in their comments that they were not relevant to their communities in terms of information gathering or informed decision-making. This was due to significant linguistic and cultural barriers - as most public campaigns and information have targeted community members where English is a first language and do not take into account literacy levels or culturally sensitive communication strategies.

\section{Low knowledge of organ and tissue donation processes and procedures}

As a result of low exposure to organ donation information, campaigns or stories it was evident that community members had a low overall awareness and understanding in regards to organ and tissue donation processes and procedures. Firstly, these included a lack of knowledge about eligibility, the registration and consent process and the status and legality of the consent processes. Community members reported these were a significant area of confusion for them and one that they had not ever directly received any education or information about.

"Nobody knows about it. I have registered as a donor but nobody knows about the system." (Macedonian Female, over 40)

"... It's probably a very thorough process but we don't know about it" (Greek Female, under 40) 
"So if the licence says yes are they still going to ask the family?" (Greek Male, over 40)

"About the organ registry, isn't that legal regardless of what your family says?" (Greek Female, over 40)

"I thought it was only the person themselves who got to decide for themselves. I didn't think the family could." (Macedonian Female, under 40)

Another area of low knowledge concerned the circumstances of death which might make a person eligible to become an organ and tissue donor. Many were also concerned and confused about what happens to a person who has consented to become an organ donor. This lack of knowledge led to a degree of reservation about committing to a process that was unclear.

"...are the organs taken from somebody who has an accident or not? Or somebody that just passed away in their old age from natural causes let's say..." (Serbian Male, over 40)

"If we are going to agree...then we really need to know what they are going to do to us when we die." (Macedonian Female, over 40)

\section{Beliefs and attitudes towards organ donation}

Low community knowledge and awareness of organ and tissue policies and procedures has led to the existence of both positive and negative beliefs and associations with organ and tissue donation. Discussions revealed both positive cultural associations with the act of donation, as well as significant fears and concerns that have led to confusion and low levels of community discussion about the subject.

\section{Positive associations with Organ Donation}

Organ Donation as an act consistent with community values

During the focus groups, some participants expressed positive associations with being or becoming an organ and tissue donor. On the positive side, organ and tissue donation was seen as a social act that was linked to positive values of altruism and charity.

"I think being an organ donor... feels good. You give your organs to help someone else." (Macedonian Male, under 40)

"...it's sort of nice, symbolic that when you pass away, you're helping someone." (Greek Male, under 40)

"...if I was to die tomorrow... it would make me the happiest person to know that I could save somebody's life." (Serbian Female, over 40) 
Organ donation was perceived by many as a worthy and generous act of charity. Within the focus groups, values underpinning charity, such as the importance of giving to those in need, were viewed as strong within the cultural groups.

Participants raised that, as migrants in a new country, they had developed a strong sense of interdependence on one another, As such, being an organ donor was seen as consistent with community values.

'This [organ donation] is consistent with our culture...we have had to give to those who are in need... and to accept gifts from others when we ourselves have been in need. This is how we have survived [as migrants], we relied on each other...we have taught these values to our children...to give to those in need' (Serbian Female, over 40)

\section{Negative and fearful associations with organ donation}

Whilst some raised the positive values associated with organ donation, tor others, being an organ or tissue donor was undesirable, or associated with concerns and/or fears.

Donation as mutilation of the body

Associated with a lack of knowledge about organ donation procedures, there were many who expressed concerns and fears in regards to organ donation resulting in the mutilation of the body of the deceased. Some feared the practical implications and the potential impact on funeral rituals, whilst others also feared possible spiritual implications in regards to the impact of donating on the body of the deceased.

"They need to look [good], it's an open coffin and you show off the body and the whole lot." (Macedonian Male, under 40)

"For us...for our religion...your body has to be buried together, without missing pieces...so I am not sure that it is right for us to do this" (Serbian Female, under 40)

Donation system as 'not trustworthy'

For some, there was also a sense of distrust in the health system, with fears that registering donor intention may lead to negative outcomes, such as not receiving lifesaving medical care.

"We are scared because if you have an accident and are an organ donor, the hospital staff will rush to take your organs rather than taking all of the medical care to save your life." (Macedonian Male, over 40)

"I've heard that if you're being kept alive by a machine or whatever and if the doctor knows that you've agreed to donate organs from your body then sometimes they switch it off earlier. I've heard that but I don't want to believe it. But you hear a lot of rumours." (Greek Female, over 40) 
For some, these concerns were mainly underpinned by fears regarding possible errors of judgement made by medical staff. Some recounted stories of where families had been told their loved ones was 'clinically dead', but had subsequently 'woken up'. In this light, fears were expressed about a haste to make a medical judgement in patients who had registered as an organ donor.

"Sometimes doctors make mistakes..." (Macedonian Female, over 40)

"What happens if you are not dead... sometimes if you're not actually dead they'll take your organs." (Serbian Female, over 40)

"... a good friend of mine... was clinically dead... his parents said the final ok... they switched off his life support and donated his organs... If they had said 'no' would he have maybe woken up? ... are people just jumping in and ... not giving this person a decent chance of recovery?" (Greek Male, under 40)

For others, these fears were also underpinned by previous experiences of perceived discrimination within the health sector. Stories were told of inadequate or discriminatory treatment received within hospitals. For some there were fears that this may also occur when determinations of death were being made in a potential migrant donor, in favour of saving a non-migrant potential recipient.

'I have seen it before...in hospitals...we [the Serbians] don't get the same treatment as others [the Australians]... and if it comes down to saving our lives or theirs [the potential recipient] I fear they will err on the side of choosing the other' (Serbian male, over 40)

Finally, another significant concern related to trust was the perception the system of organ acquisition and transplantation may be open to corruption - due partly to an awareness of an 'international organ trade' which they had heard about in the international media.

"My only concern is corruption. We all read in the local Serbian newspapers... I just hope that this doesn't happen in Australia." (Serbian Male, over 40)

Discussion of donation as undesirable or 'taboo'

Overall, many of these fears and concerns led to the discussion of organ and tissue donation as uncomfortable and undesirable within the communities. This was raised by many participants within the group who noted a resistance within families and communities to talk about this issue.

"I didn't want to scare them because they'll say, "Oh you're thinking about death". (Macedonian Male, under 40)

"I tried to [talk about organ donation] but my family doesn't want to hear about it." (Serbian Male, under 40) 
"I guess talking about your children dying is a very emotional thing ... and also I think there's a bit of a barrier about talking about death. Not just within the Greek community but also the wider community." (Greek Female, over 40)

Some highlighted that discussion of organ and tissue donation was not only uncomfortable but taboo. There were superstitions about the discussion of death. For instance some felt that there was a view in their community that speaking about organ and tissue donation was talking about death and talking about it may lead to death actually occurring.

"I think it is taboo [talking about organ donation] in a Macedonian community, in a big way" (Macedonian Female, under 40)

"A lot of people believe that if you don't talk about things they won't come. It's reality! It sounds ridiculous but it's true." (Macedonian female, under 40)

"I'm afraid to say something, maybe I will die." (Serbian Female, over 40)

\section{Confusion regarding Orthodox religious perspectives on organ donation}

In the midst of the low knowledge and fear, there was also significant confusion in regards to the Orthodox religious perspectives on organ donation. From a religious point of view some community members believed there may be some restrictions to organ and tissue donation from the perspective of the Orthodox teachings.

"Religion... desecrating the body... the spirit... religiously we have been taught that you don't muck around with the body after you pass away. You're supposed to just go back in the ground as you were, as per the Bible." (Greek Female, under 40)

"No I want to go to the afterlife with my whole body and whole organs. My late father gave the example - how I was born that's how I'm going to go to the other world. That was how he was raised and that's his religion and belief." (Serbian Female, over 40)

However, others felt there was unlikely to be any religion-based opposition.

"We are not aware of any restrictions according to the religion." (Macedonian Male, over 40)

"I've heard nothing in our religion that is the stopping point." (Greek Male, over 40)

"In our religion they say we only have our soul and on the outside is only a shell. If that's the case why are we scared?" (Serbian Female, over 40)

Overall, due to the lack of agreement, there was an expressed desire for clarification to be gained from religious leaders and a desire to understand whether it is an accepted or normative practice.

"I think it just needs to be brought up. I've never heard it been brought up. It's never been brought up in our church." (Macedonian Female, under 40) 


\section{Perceived Community Barriers and Needs - improving the promotion of Organ and Tissue Donation}

Overall, superstitions and discomfort regarding the discussing of death (and therefore organ and tissue donation) were considered the primary barrier to the promotion of organ and tissue donation within all three orthodox communities. A lack of culturally and linguistically specific resources/materials that answered their questions along with limited access to 'experts' to ask questions and clarify issues of concern were seen as significant barriers to the issue being embraced and openly discussed.

"It's very hard to make a decision because we are not informed enough... if the people were informed about the procedure then they would be more comfortable... there are misconceptions and they don't understand the whole procedure and that's where the fear comes." (Serbian Female, under 40)

"We've never been taken through it, we don't really know much about it. So it's probably a very thorough process but we don't know about it." (Greek female, under 40)

Community members felt that they would benefit from information and opportunities which would provide them with a better understanding of the views of other members of their community. Interestingly, opportunities to discuss beliefs and attitudes within their community were also desired, despite personal discussion with family and loved ones being perceived as difficult.

"It's a matter of just getting it out there and just being open with each other..." (Macedonian Female, under 40)

"I think we need to hold conversations like this." (Serbian Male, under 40)

Overall, the community identified a desire for access to information from three types of experts to build both understanding and trust. These were organ donation 'medical experts', religious leaders (regarding the Church and spiritual perspectives); and also the 'expertise' or testimony of people who had experienced 'the system' - particularly members of their own community.

\section{DISCUSSION}

The current study found low awareness and understanding within the Serbian, Macedonian and Greek Orthodox communities regarding organ and tissue donation processes and procedures. This included a lack of knowledge regarding who is eligible for organ and tissue donation, what happens to the body during organ and tissue donation, the allocation of organs and the requirement of family consent. In an international review, greater awareness or knowledge of organ donation processes and procedures was found in a number of studies to be predictive of more positive attitudes, which in turn are predictive of intentions to donate and to join a registry (5). Participants in the current study reported 
misinformation and myths circulating with regard to organ donation. Lack of knowledge/awareness and myths /misconceptions of organ donation have been previously identified as a common phenomenon for ethnic minorities (25). Calls have been made for culturally appropriate and linguistically relevant health education programs targeting ethnic minority populations to affect positive change in knowledge, attitudes, and behavior (25). Participants in the current study also expressed a need for culturally specific resources/materials that answered their questions and access to 'experts' to ask questions and clarify issues of concern. Importantly, the 'expertise' identified as important by the community was desired at three levels: medical expertise; religious and ethical expertise; and 'community' expertise (particularly from community members who had had experience with the organ and tissue donation system).

There was a sense of distrust in the health system among participants, with fears that donors would not receive lifesaving medical care. Some believed there was the possibility for errors of judgement to be made by medical staff. A concern for some participants was the perception the system of organ acquisition and transplantation may be open to corruption. This for some had been based on their own experiences of perceived discrimination within the health system. Similar findings from a qualitative study have been reported (38) and mistrust in the medical system has been found to be a negative predictor of organ donation (13). A survey of African Americans (16) found that, in addition to lower willingness to donate their own or a family member's organs (compared to Caucasian counterparts), they were more likely to report a distrust of the medical system (such as; 'rich and famous people are more likely to get a transplant'; 'doctors can't be trusted to pronounce death'; and 'organ donors do not receive life-saving medical care'. This factor made the 'expertise' and testimony of members from within their own community particularly important, as experience of the system could be tested against perceptions of fairness and equity.

For the majority of participants discussion of organ and tissue donation was seen as uncomfortable and undesirable and many were resistant to family or community discussions. This finding is important given the requirement for family consent in the organ and tissue donation process in Australia, and findings from other studies that show positive familial influences are a predictor of willingness to donate (5). Participant discomfort to discuss organ and tissue donation was often linked to beliefs and superstitions about death.

Finally, some participants expressed an unwillingness to donate because they felt it was important to maintain the integrity of the deceased body so that it could be viewed as part of funeral rituals and/or make transition to an afterlife. Similar findings have been reported in studies in other countries (24, 38-40). For example, a US study (24) found that people who did not wish to think about death, or were concerned about their need for organs in the afterlife, or the appearance of the body in an open casket after death were less willing to donate. This raises the importance for health educators and donor co-ordinators to both identify and prioritise the specific death and funeral rites within diverse cultural groups, and the specific needs within 
each particular cultural group in an attempt to establish greater acceptance of the organ donation process as 'acceptable' within their rites and traditions.

Finally, some participants expressed positive beliefs and perceived organ and tissue donation as an act of altruism that was linked to their cultural and religious values. Other studies have found that individuals who have altruistic beliefs about helping others are more likely to be willing to discuss organ donation, to donate and/or enrol in an organ donation registry (5). Importantly, the focus groups revealed a lack of community awareness about either restrictions or support for organ and tissue donation from the perspective of the Orthodox churches and expressed desire for clarification from religious leaders as to whether it is an accepted or normative practice. In Australia, the Greek Orthodox Church in Australia has released a position statement supporting the practice of organ donation (41). However, less clarity was found for a formal position from within the Serbian and Macedonian Orthodox communities. For example one Orthodox website (42) states: "While some believe that organ donation is a desecration of the temple of the Holy Spirit, others believe that it is a wonderful, self-sacrificial way of showing love for God and neighbor. Though there are differing perspectives on the matters within the Church as a whole, they are all united in emphasizing that, when weighing such a heavy decision, it is absolutely imperative to consult a spiritual father, and pray unceasingly on the matter." Suggestions to clarify the attitudes of religious communities and engage the support of religious leaders have been made by other researchers considering the effects of religiousness on organ donation (22-24). Results from this study underscore the particular importance of the engagement of religious leaders within their communities, particularly when considering the members desire to discuss and ask religious, ethical and moral questions of their leaders. Given the study also highlights the predominantly 'passive' information seeking strategies in regards to information about organ and tissue donation, it also remains likely that a formal statement or published position alone, without an active engagement process is unlikely to reach community members.

\section{CONCLUSION}

Formative research with the three communities highlighted that there were significant barriers to discussing and making an informed decision about whether or not to become an organ and tissue donor. Knowledge of organ and tissue donation processes and procedures was very low. There was also a strong belief that talking about organ and tissue donation, particularly with loved ones, was undesirable and uncomfortable. This meant that there was little opportunity for community members to address the fears they had about the organ and tissue donation process,

including the potential for corruption or mistreatment by medical personnel. All three communities expressed a strong desire for information on organ and tissue donation that was culturally appropriate and linguistically relevant and opportunities to discuss the issues as a community. Useful information included 'expert' responses to their questions from medical personnel, as well as clarification from churches and 
local religious leaders, and testimonies from people who had been personally involved in both the donation and receipt of organs and tissues. Future educational programs and campaigns seeking to engage religious and minority cultural groups should consider the need for the active consultation and engagement with the community and the provision of information and opportunities to benefit from the three levels of 'experts' designated as important by the community.

\section{REFERENCES}

1. World Health Organisation. Draft guiding principles on human organ transplantation. 2013 [cited 201314 November]; Available from:

http://www.who.int/ethics/topics/transplantation_guiding_principles/en/index1.html. Accessed 8.24 .14

2. Schnitzler MA, Whiting JF, Brennan DC, Lentine KL, Desai NM, Chapman W, et al. The life-years saved by a deceased organ donor. Am J Transplant. 2005;5(9):2289-96.

3. The Organ Procurement and Transplantation Network. Uniting people and information to help save lives. US Department of Health and Human Services; 2013 [cited 201314 November]; Available from: http://optn.transplant.hrsa.gov/. accessed 8.24.14

4. Organ and Tissue Authority. Performance Report. Australian Government,; 2012 ; Available from: http://www.donatelife.gov.au/media/docs/performance report for 2012.pdf. accessed August 24, 2014.

5. Wakefield CE, Watts KJ, Homewood J, Meiser B, Siminoff LA. Attitudes toward organ donation and donor behavior: a review of the international literature. Prog Transplant., 2010;20(4):380-91.

6. Organ and Tissue Authority. Facts and Statistics. 2013 [cited 201314 November]; Available from: http://www.donatelife.gov.au/discover/facts-a-statistics. Accessed home site 8.24.14

7. Medicare. Australian Organ Donation Register Statistics. Australian Government, Department of Human Services; 2013 [cited 2013 December 13 ]; Available from:

http://www.medicareaustralia.gov.au/provider/patients/aodr/stats.jsp. Accessed 8.24.14

8. Wakefield CE, Reid J, Homewood J. Religious and ethnic influences on willingness to donate organs and donor behavior: an Australian perspective. Prog Transplant. 2011;21(2):161-8.

9. Alvaro EM, Jones SP, Robles ASM, Siegel J. Hispanic organ donation: impact of a Spanishlanguage organ donation campaign. Journal of the National Medical Association. 2006;98(1):28-35. 10. Evers KA, Lewis DD, Schaeffer MJ. Sociological and cultural factors affecting consent for organ donation. Crit Care Nurse. 1999;19(4):57-61.

11. Holden C. Random Samples: Who Donates Organs? Science. 2005;309(5731):47

12. Salim A, Berry C, Ley EJ, Schulman D, Desai C, Navarro S, et al. The impact of race on organ donation rates in Southern California. J Am Coll Surg. 2010;211(5):596-600. doi: 10.1016/j.jamcollsurg.2010.06.390.

13. Boulware LE, Ratner LE, Sosa JA, Cooper LA, LaVeist TA, Powe NR. Determinants of willingness to donate living related and cadaveric organs: identifying opportunities for intervention. Transplantation. 2002;73(10):1683 - 91.14. Kopfman JE, Smith SW, Morrison K, Massi L, Yoo HJ. Influence of race on cognitive and affective reactions to organ donation messages. Transplant Proc. 2002;34(8):3035-41.

15. Minniefield WJ, Yang J, Muti P. Differences in attitudes toward organ donation among African Americans and whites in the United States. J Natl Med Assoc. 2001;93(10):372-9.

16. Siminoff LA, Burant CJ, Ibrahim SA. Racial disparities in preferences and perceptions regarding organ donation. J Gen Intern Med. 2006;21(9):995-1000.

17. Cheung AH, Alden DL, Wheeler MS. Cultural attitudes of Asian-Americans toward death adversely impact organ donation. Transplant Proc. 1998;30(7):3609-10.

18. Ozer A, Ekerbicer HC, Celik M, Nacar M. Knowledge, attitudes, and behaviors of officials of religion About organ donation in Kahramanmaras, an eastern Mediterranean city of Turkey.

Transplant Proc. 2010;42(9):3363-7. doi: 10.1016/j.transproceed.2010.08.035. 
19. Morgan M, Mayblin M, Jones R. Ethnicity and registration as a kidney donor: the significance of identity and belonging. Soc Sci Med. 2008;66(1):147-58.

20. Faraj W, Fakih H, Mukherji D, Khalife M. Organ donation after cardiac death in the Middle East. Transplant Proc. 2010;42(3):713-5. doi: 10.1016/j.transproceed.2010.02.058.

21. Shaheen FA. Organ donation in the Middle East countries. Ethn Dis. 2009;19(1 Suppl 1):S1$16-7$.

22. Saleem T, Ishaque S, Habib N, Hussain SS, Jawed A, Khan AA, et al. Knowledge, attitudes and practices survey on organ donation among a selected adult population of Pakistan. BMC Med Ethics. 2009;10:5. doi: 10.1186/1472-6939-10-5. 23. Rumsey S, Hurford DP, Cole AK. Influence of knowledge and religiousness on attitudes toward organ donation. Transplant Proc.

2003;35(8):2845-50.

24. Skowronski JJ. On the Psychology of Organ Donation: Attitudinal and Situational Factors Related to the Willingness to Be an Organ Donor. Basic Appl Soc Psych. 1997;19(4):427-56

25. Callender CO, Miles PV. Obstacles to organ donation in ethnic minorities. Pediatr Transplant. 2001;5(6):383-5.

26. Woolcott Market Research. Culturally and Linguistically Diverse Audiences Research. Canberra, Australia: Donate Life, Organ and Tissue Authority, Australian Goverment; 2011.

27. Australian and New Zealand Organ Donation Registry. Summary of Organ Donation in Australia and New Zealand, 2007-2011. In: ANZOD, editor. Canberra, Australia: Australian and New Zealand Organ Donation Registry; 2012.

28. US Department of Health and Human Services. Why Minority Donors are needed.

Washington, United States: U.S. Department of Health and Human Services; 2013 [cited 2013

December 13]; Available from: http://organdonor.gov/whydonate/minorities.html. Accessed 8.24.14

29. Donate Life. Agency Multicultural Plan 2013-2015. In: Authority OaT, editor. Canberra: Commonwealth Government of Australia; 2013.

30. Georgiadou E, Sounidakis N, Mouloudi E, Giaglis P, Giasnetsova T, Marmanidou K, et al. Attitudes and behavior toward organ donation in Greece. Transplant Proc. 2012;44(9):2698-701. doi: 10.1016/j.transproceed.2012.09.017.

31. Australian Bureaus of Statistics. 2011 Census QuickStats. Canberra, Australia: Australian Bureau of Statistics; 2011 [cited 2013 December 16]; Available from:

http://www.censusdata.abs.gov.au/census_services/getproduct/census/2011/quickstat/107?opendocum ent\&navpos=220. Accessed 8.24.14

32. Phillipson L, Larsen-Troung K, Jones S, Pitts L, Nonu M, Filippi M, et al. Addressing stigma and engaging orthodox religious communities around organ and tissue donation. 12th Congress of the International Society for Organ Donation and Procurement; November 21-24; Sydney, Australia: Transplantation; 2013.

33. Wong JP, Poon MK. Bringing translation out of the shadows: translation as an issue of methodological significance in cross-cultural qualitative research. J Transcult Nurs, 2010;21(2):151-8. doi: $10.1177 / 1043659609357637$.

34. Björk Brämberg E, Dahlberg K. Interpreters in cross-cultural interviews: a three-way coconstruction of data. Qual Health Res. 2013;23(2):241-7. doi: 10.1177/1049732312467705. 35. Donate Life. 'Know their Wishes' Campaign TV Advertisement. Organ and Tissue Authority, Commonwealth Government of Australia; 2011. Available at

http://www.donatelife.gov.au/resources/donatelife-campaign/know-their-wishes-campaign Accessed $8-24-2014$

36. Stewart, D.W. and Shamdasani, P.N. Focus Groups. Theory and Practice. Sage Publications, 1990.

37. Esposito N. From meaning to meaning: the influence of translation techniques on non-English focus group research. Qual Health Res. 2001;11(4):568-79.38. Alden DL, Cheung AH. Organ donation and culture: a comparison of Asian American and European American beliefs, attitudes, and behaviors. J of Appl Soc Psychol. 2000;30(2):293-314.

39. Conesa C, Ríos A, Ramírez P, Rodríguez MM, Rivas P, Canteras M, et al. Psychosocial profile in favor of organ donation. Transplant Proc. 2003;35(4):1276-81. 
40. Conesa C, Ríos A, Ramírez P, Cantéras M, Rodríguez MM, Parrilla P, et al. Attitudes toward organ donation in rural areas of southeastern Spain. Transplant Proc. 2006;38(3):866-8.

41. Archbishop Stylianos. Position Statement, Greek Orthodox Church. Donate Life; 2013;

Available from:

http://www.donatelife.gov.au/media/docs/CALD/2013.04.17 ORGAN DONATION ENCYCLICAL .pdf. Accessed 8-24-2014

42. Wiki O. Organ donation. 2008. Available at http://orthodoxwiki.org/Organ_donation. Accessed 8-24-2014 